\title{
Institutional analysis of forest governance after the implementation of Law Number 23/2014 in North Sumatra Province, Indonesia
}

\author{
Oding Affandi ${ }^{1,2^{*}}$, Hariadi Kartodihardjo ${ }^{3}$, Bramasto Nugroho ${ }^{3}$, Sulistya Ekawati ${ }^{4}$ \\ ${ }^{1}$ Graduate Program of Forest Management Science, Faculty of Forestry, IPB University, Bogor, Indonesia \\ ${ }^{2}$ Faculty of Forestry, Universitas Sumatera Utara, Medan, Indonesia \\ ${ }^{3}$ Faculty of Forestry, IPB University, Bogor, Indonesia \\ ${ }^{4}$ Center for Social, Economic, Policy and Climate Change Research and Development, Ministry of \\ Environment and Forestry, Bogor, Indonesia \\ * Correspondence author: oding@usu.ac.id; Tel.: +62-819-7319-6430
}

\begin{abstract}
After the implementation of Law Number 23/2014 on Regional Government in Indonesia, the authority for forest management rests with the central and provincial governments. This study aims to (1) assess forest governance performance after the implementation of this law, (2) analyse the institutional aspects of forest governance after the implementation of this law and (3) formulate strategies to strengthen forest governance institutions. This study finds that although Law Number 23/2014 has been implemented in North Sumatra Province, the forestry sector remains centralistic; the characteristics of forest resources have not changed (these continue to be common pool resources) and the behaviour of the actors lacks synergy. In this scenario, the performance of forest governance has not improved significantly, as indicated by the incomplete designation of forest areas; the number of Kesatuan Pengelolaan Hutan that have not implemented the Badan Layanan Umum Daerah scheme; the low rights of access and low forest utilisation by the community; and the slow service process for permits; however, the costs for obtaining permits are according to regulations. This is in line with the results of this study's institutional analysis, which show that (1) the provincial jurisdiction boundaries have narrowed, given that only the central government has authority over the forestry planning sub-function and forestry supervision; (2) many central government regulations continue to be used in forest management, characterising the low aspect of provincial regional representation rules; and (3) despite clear forest ownership rights, there are claims from other stakeholders, which indicates the low legitimacy of the parties. This study suggests that forest governance performance can be improved by expanding the jurisdiction boundaries through the assistance task mechanism to the provincial government; ensuring provincial government participation in formulating forest policies; and increasing the status of forest permit holders and managers from claimants to proprietors.
\end{abstract}

Keywords: institutional; forest governance; implementation of Law Number 23/2014; North Sumatra Province

\section{Introduction}

In aiming to achieve decentralisation, Indonesia implemented Law Number 32/2004 on Regional Government to decentralise the authority to manage forest resources from the central government to the provincial and the regency governments. Regency governments were authorised to manage forest areas within their administrative areas through actions such as planning forest management, issuing forest utilisation permits, rehabilitating and reforesting forest areas, protecting forests and empowering the communities near forests (Simarmata \& Firdaus, 2016). The implementation of this law resulted in Indonesia's forest governance being included in the bad-tomedium category (Indrarto et al., 2012; Kartikasari et al., 2012; United Nations Development Programme [UNDP] Indonesia, 2013, 2015). Further, Rahman et al. (2013), Indonesian Center for Environmental Law and Sekretariat Nasional Forum Indonesia untuk Transparansi Anggaran (SEKNAS FITRA, 2015) and Handayani et al. (2019) also found that forest management by regency governments typically failed to achieve the principles of good forest governance (GFG). This 
situation illustrates that, in the decentralisation era, forest management performance in Indonesia, both at the central and local levels, did not fully comply with GFG principles.

GFG is interpreted as structuring the mechanism of the interrelationships of actors in forest management through various controlling instruments to achieve common goals associated with managing forest resources, providing goods and services in a sustainable manner and supporting community prosperity (Nugroho, 2013; Secco et al., 2014). GFG is significantly influenced by the institutional of forest governance. The institutional is defined as the rules, norms, prohibitions, contracts, policies and regulations that regulate and control the behaviour of individuals in society or organisations to reduce uncertainty in controlling their environment and to inhibit the emergence of opportunistic behaviour and mutual harm for ensuring more predictable human behaviour towards maximising individual prosperity (North, 1990; Nugroho, 2016; Peters, 2000). However, in the institutional context of Indonesia, GFG has not yet been achieved in the forestry sector, generally because of institutional failures in forest management. First, the regulations have failed to address key problems, have incurred high implementation costs, have been susceptible to being affected by the behaviour of uncontrolled actors and have not specified well-defined property rights. Second, organisational capacity is weak, meaning that institutions are unable to implement existing rules owing to low human resource capacity, limited funding support, lack of community participation in decision-making and lack of accountability mechanisms (North, 1990; Nugroho, 2013; Peters, 2000).

In addition, Law Number 32/2004 had a weakness in that governors could not regulate the issuance of mining, marine and forestry permits by the regency/local governments. This limitation led to severe environmental damage due to the overexploitation of natural resources by regency/municipality governments in order to increase local revenues. Even in the case of forest function conversion, misappropriation often occurred, and the officials involved tended to engage in corrupt practices, causing the state to lose revenues. The implementation of Law Number $32 / 2004$ also often created uncertainty in the division of governmental affairs between the central government and the provincial regions, resulting in conflict and overlapping authorities (Colfer \& Capistrano, 2005; Moeliono et al., 2008; Ministry of Home Affairs [MoHA], 2011). Therefore, this situation prompted the issuance of Law Number 23/2014 on Regional Government as a substitute for Law Number 32/2004 (Simarmata \& Firdaus, 2016).

The implementation of Law Number $23 / 2014$ has led to a substantial change in regulations regarding the division of forest management authority, and it places forests under the jurisdiction of the central and provincial governments. At the provincial level, forest management units or Kesatuan Pengelolaan Hutan (KPHs) are being established to manage forests at the site level. This has resulted in a loss of focus on regional autonomy in forest management by the regency/municipality. In other words, the provisions about forestry affairs in Law Number 23/2014 are an effort to re-centralise forest management (Maryudi, 2016; Sahide et al., 2016; Setyarso et al., 2014; UNDP Indonesia, 2015). Although provinces have a provincial government that has considerable authority, it is actually an extension of the central government through the concept of deconcentration. ${ }^{1}$ Thus, the implementation of Law Number 23/2014 extends the provincial regions' range of control and effectiveness of forest management at a time when the readiness of the $\mathrm{KPH}$, as the site-level forest manager, remains low. Thus, the law becomes an obstacle in improving forest governance performance (Simarmata \& Firdaus, 2016).

During the implementation of Law Number 32/2004 (until 2014) in North Sumatra Province, forest management was affected by some crucial issues, including the incomplete designation of forest areas, community claims and conflicts over these areas, the encroachment and conversion of forest areas, illegal logging activities, low human resource capacity to enforce the law, conflicts between communities and wildlife and weak law enforcement (Corruption Eradication Commission/Komisi Pemberantasan Korupsi [KPK], 2012; Indonesian Center for Environmental Law

\footnotetext{
${ }^{1}$ Deconcentration is the delegation of part of governmental affairs, which is the authority of the central government to the governor as the representative of the central government, to vertical agencies in certain areas, and/or to the governor and the regent/mayor as the person in charge of general government affairs (Law Number 23/2014 Article 1 section (9)).
} 
\& SEKNAS FITRA, 2015; Indrarto et al., 2012; UNDP Indonesia, 2015 ). However, those problems persist even after the implementation of Law Number 23/2014 (Basyuni et al., 2018; Forestry Service of North Sumatra Province, 2019; Handayani et al., 2019).

Given that the implementation of Law Number 23/2014 has not overcome forest management problems, such as the increasing burden on provincial forest management due to spillovers from regencies/municipalities and the lack of readiness of the provinces to perform their assigned responsibilities, as well as the decentralisation of forest management, certain questions are raised: How effective is the current forest management, which used to be carried out by regencies/municipalities earlier? How do provinces plan, manage and prepare forest governance rules and policies? How do provinces develop innovations to improve forest governance performance?

Experiences from various countries show that the division of forest management authority between the central and local governments in a decentralised system is very dynamic. In this case, there are three requirements to develop an effective decentralised system that is able to improve forest governance performance: (1) an appropriate, effective division of authority in making decisions and collecting revenues based on the capabilities and needs of each government level; (2) effective law enforcement and accountability at all government levels to ensure that government agencies fairly and efficiently carry out their mandates; and (3) effective linkages with other sectors that affect, or are influenced by, the forestry sector (Colfer \& Capistrano, 2005; Food and Agriculture Organization Program on Forests, 2011). In contrast, efforts to change institutions and to separate forest management authority between the central and local governments are sometimes not followed by a renewal of the philosophical foundation and framework used. Consequently, regulations and institutions have increased and the names of institutions are often changed, but the type of policies implemented has not changed, which thus does not change the onsite performance (Kartodihardjo, 2006; 2008).

Although these problems are complicated, forest management authority has shifted from the regency/municipality government to the provincial government after Law Number 23/2014 was implemented. In this case, the provincial government is unable to automatically solve forest management problems, which would result in improved forest governance performance. Therefore, the increase in provincial authority must be accompanied by institutional strengthening and innovation. This step is important because it is essential to improve forest governance performance by the provincial government. In addition, other reasons for the importance of institutional strengthening include the following: Forest governance performance is influenced by various rules, both formal and informal (i.e. institutional structure); forest resources are easily accessible and open to all parties (i.e. resource characteristics) and actors' responses and behaviour (i.e. actor behaviours) vary according to their interests and powers (Kartodihardjo, 2006, 2013; Nugroho, 2013, 2016; Ostrom, 2008; Reed et al., 2009).

The institutional framework approach that Nugroho (2016) developed considers that performance achievement is closely related to the relationship and the mutual influence between institutional components, namely, institutional structure, resource characteristics and actor behaviour. Further, Pakpahan (1989) and Kartodihardjo (2008) stated that three institutional aspects play a key role in achieving successful governance performance: jurisdictional boundaries, rules of representation and ownership rights. Therefore, in this study, we aim to (1) assess the achievement of forest governance performance after the implementation of Law Number 23/2014 in North Sumatra Province, (2) analyse the institutional aspects of forest governance after the implementation of this law and (3) formulate strategies for strengthening forest governance institutions.

\section{Research Methods}

\subsection{Research Location}

We conducted this study in North Sumatra Province, focusing on the North Sumatra Provincial Forestry Service. The sample of this study is the Technical Implementation Unit (Unit Pelaksana 
Teknis or UPT) of the Forest Service, including KPH Region I Stabat (Langkat Regency), KPH Region IX Panyabungan (Mandailing Natal Regency) and KPH Region X Padang Sidempuan (South Tapanuli Regency; see Figure 1).

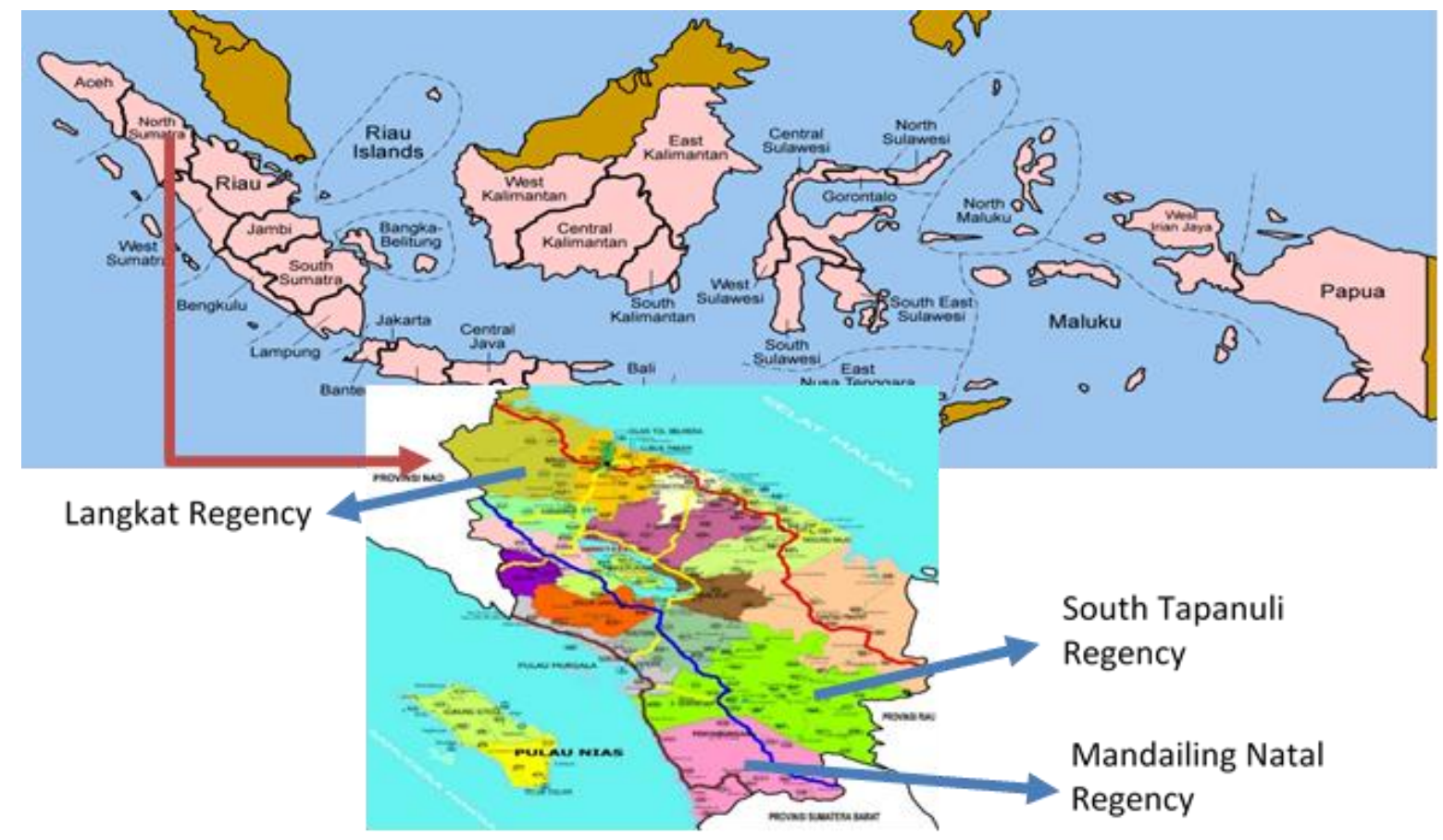

Figure 1. Research location

\subsection{Data Collection and Analysis}

We used a mixed methods approach to collect quantitative data (e.g. through content and document analyses, and a survey) and qualitative data (e.g. through interviews and focus group discussions [FGDs]) from January to December 2018. We conducted interviews and FGDs with stakeholders involved in forest governance. The key respondents for each stakeholder ranged from two to five individuals. For more details on the quantitative and qualitative data we used in this study, see Table 1.

The data collection process comprised the following stages:

Identifying the applicable regulations and policies related to forest governance (focusing on aspects of the division of authority in forest management, especially under Law Number 23/2014).

1) Analysing the content of the rules and policies related to forest governance. In the content analysis approach, researchers try to analyse/evaluate text data, images and expressions that are created to be read, interpreted and have meaning. The main point of this analysis approach is to identify patterns and to classify and evaluate text manifestations (Handoyo et al., 2013)

2) Analysing changes in the characteristics of forest resources as common pool resources (CPRs). This analysis is important because the resource characteristics influence and determine the relationships between actors and influence their behaviour in taking advantage of forest resources.

3) Identifying actors involved in forest governance (individuals and groups) and analysing their behaviour, level of power/authority and interests in forest governance institutions.

We use a descriptive method to analyse the relationship between the implementation of Law Number 23/2014 and forest governance performance. In this case, Law Number 23/2014 was effective in improving forest governance performance, owing to the complex problems in forest management as regards policy, forest resources and human resources. Therefore, for the analysis in this study, we use a multi-factor framework with the institutional analysis model that Nugroho (2016) developed. Performance achievement is influenced by three institutional components: institutional structure, resource characteristics and actor behaviour. The first two components will 
influence each other. Both components will influence actors, which in turn, will affect institutional performance (Figure 2).

Table 1. Quantitative and qualitative research methodologies

\begin{tabular}{|c|c|c|}
\hline Methodology & $\begin{array}{l}\text { Data collection } \\
\text { technique }\end{array}$ & Data source \\
\hline \multirow[t]{4}{*}{ Quantitative } & Content analysis & $\begin{array}{l}\text { Regulations and policies: Law Number } 23 / 2014 \text {, Law Number } 32 / 2004 \text {, } \\
\text { Law Number } 41 / 1999 \text {, The Regulation of The MoEF Number P.83/2016 } \\
\text { and The Regulation of The MoHA Number } 79 / 2019 \text { on Local Public } \\
\text { Service Agency (Badan Layanan Umum Daerah or BLUD) }\end{array}$ \\
\hline & & Mass media news \\
\hline & Document analysis & $\begin{array}{l}\text { Research and document report; Provincial Forest Service Strategic Plan; } \\
\text { KPH Long-Term Forest Management Plan Book; Annual Work Plan for a } \\
\text { timber business licence holder, etc.). }\end{array}$ \\
\hline & $\begin{array}{l}\text { Survey } \\
\text { (observation) }\end{array}$ & $\begin{array}{l}\text { Stakeholder in forest governance, certainty of forest area, KPH } \\
\text { operation at site level, the ratio of the use of forest areas by } \\
\text { communities and corporations }\end{array}$ \\
\hline Qualitative & $\begin{array}{l}\text { Interview and } \\
\text { focus group } \\
\text { discussion (FGD) }\end{array}$ & $\begin{array}{l}\text { Characteristic of resources, interest level and behaviour of stakeholders } \\
\text { in forest governance, opinion matrix of business actors about managing } \\
\text { licences and using forest areas }\end{array}$ \\
\hline
\end{tabular}

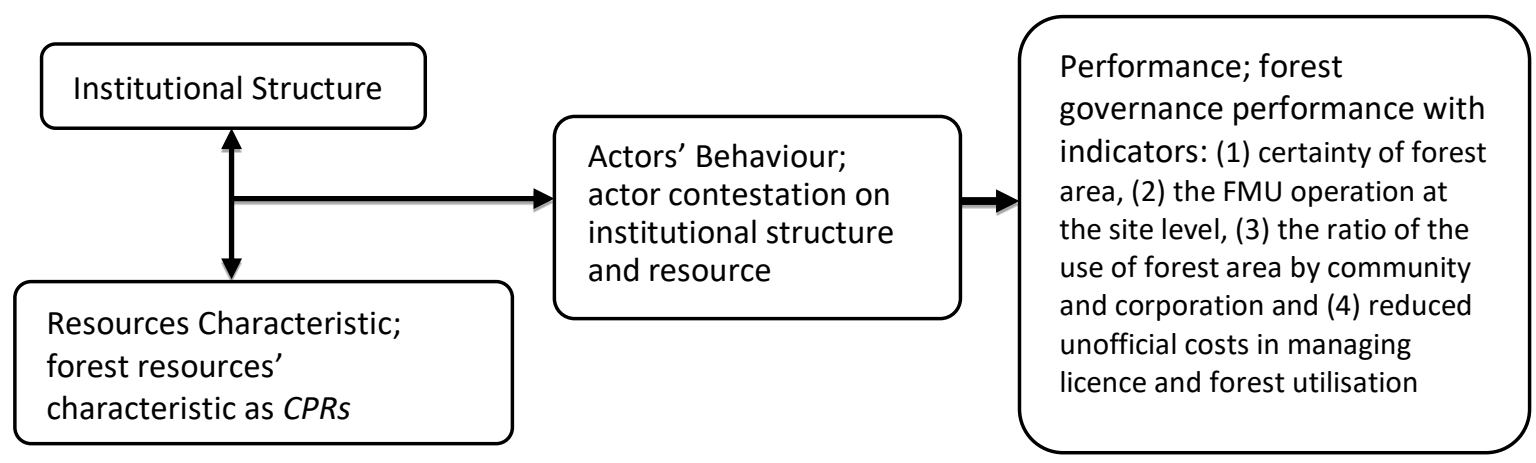

Figure 2. General framework of institutional analysis of forest governance performance after the implementation of Law Number 23/2014 in North Sumatra Province, Indonesia (modified from Nugroho, 2016)

Institutional structures can be formal institutions (e.g. laws and regulations, property right rules, and contracts) or informal institutions (e.g. taboos, traditions, codes of conduct, norms and habits; North, 1990). Characteristics of resources include physical characteristics (e.g. availability in nature, productivity and economic value) and CPR characteristics (easy to exclude/excludability; scarcity and competition/subtractability; Ostrom, 2008; Schmid, 2004).

Meanwhile, actors' behaviour is interpreted as their response or reaction to the institutional structure and the characteristics of the natural resource utilised. Actors include governments at various levels, affected communities, non-government organisations, universities, corporations and even individuals who use the resource (Ostrom, 2005). The results of interactions and activities among actors in the institutional structure for certain resource characteristics would produce a certain performance aimed at the preservation of stocks and flow (Nugroho, 2016). The actors are identified by considering their position of interest and influence (power). Further, they are grouped as follows: (1) key actors, who have legal authority in terms of decision-making from the legislative element, the executive element according to their level and the elements of related agencies; (2) primary actors, who have a direct interest relationship or are directly affected by an activity or policy; they generally have a high level of importance and influence; and (3) supporting actors, who do not have a direct interest in an activity or policy; they have a high level of importance but a low level of influence (Fletcher et al., 2003). 
The results of actors' interactions and activities in the institutional structure for a certain resource characteristic would produce a performance aimed at the sustainability of stock and the flow of benefits. Stock is related to the physical characteristics of resources, whereas flow is related to the characteristics of supply and consumption of a resource (Nugroho, 2016). Many indicators can be used to assess the forest governance performance of stock and flow, depending on the purpose and case (context) of the analysis. In this study, we used the following performance indicators of forest governance: (1) the certainty of forest area, based on forest area gazettement, (2) the ratio of utilisation of forest area by communities and corporations, (3) the operation of KPHs at the site level and (4) the reduction of unofficial costs (transaction costs) in managing permits and forest utilisation (Nugroho, 2016; UNDP Indonesia, 2015).

Further, Pakpahan (1989), Kartodihardjo (2008) and Rachman (2009) stated that institutional structures are human innovations that help regulate or control interdependence between parties on forest resources through property rights, jurisdictional boundaries and rules of representation. Property rights explain a person's relationship with another person through the recognition of resources and will determine their position in relation to the resource, whether as the owner, the proprietor, the claimant or the authorised user. A jurisdictional boundary determines who and what is covered in the organisation. The concept of jurisdictional boundaries can be interpreted as the limit of authority or territory of an institution in regulating resources. Rules of representation are a set of rules that determine the mechanism of organisational decision-making. The rules of representation used in the decision-making process will determine the form of decisions taken that will affect the institutional performance.

\section{Results and Discussion}

\subsection{Achievement of Forest Governance Performance After the Implementation of Law Number} 23/2014 in North Sumatra Province

\subsubsection{Institutional structure}

The institutional structure analysed in this study is Law Number 23/2014. Our content analysis approach revealed that several articles govern forest management, both directly and indirectly, including:

1) Article 9 paragraph (3): Concurrent governmental affairs are governmental affairs that are divided between the central government and provincial and regency/municipality governments.

2) Article 11 paragraph (1): Concurrent governmental affairs consist of mandatory and optional government affairs handled by regional authorities. ${ }^{2}$

3) Article 12 paragraph (3): Optional government affairs as referred to in Article 11 paragraph (1) include the forestry sector.

4) Article 14: Section (1) Government administration in the field of forestry, marine affairs, and energy and mineral resources is shared among the central and provincial governments, and section (2) Government Affairs in the forestry sector related to management of regency/municipal forest parks (taman hutan raya or Tahura) are under the regency/municipal government.

The aforementioned articles indicate that the withdrawal of regency/municipality authority in forest management has resulted in the loss of focus on regional autonomy in the regency/municipality, including: (a) a drastic reduction in regional budgets, (b) the absence of a Special Regional Government Agency dealing with forestry in the regency/municipality, (c) the loss of regency/municipality government authority to issue regional regulations about forest management and (d) the loss of authority to issue various forestry permits. In addition, it has resulted in increasing provincial responsibilities in forest management (Simarmata \& Firdaus, 2016). Therefore, North Sumatra Province has identified $16 \mathrm{KPH}$ areas for site-level forest management

\footnotetext{
2 Optional government affairs are government affairs that must be conducted by the region in accordance with the potential of the region (Law Number 23/2014 Article 1 point 15).
} 
and has drafted regional regulations on forest area management for the Province (Forestry Service of North Sumatra Province, 2019).

The division of concurrent government affairs between the central and provincial governments is listed in the Annex to Law Number 23/2014 (see Table 2).

Table 2. Illustrative diagram of the division of government affairs in the forestry sector based on Law No. 23/2014

\begin{tabular}{|c|c|c|c|}
\hline \multirow{2}{*}{ No. } & \multicolumn{3}{|c|}{ Sub-Affairs } \\
\hline & Central government & Provincial government & Regency government \\
\hline 1 & Forest planning & - & - \\
\hline 2 & Forest management & Forest management & - \\
\hline 3 & $\begin{array}{l}\text { Conservation of resources, biological } \\
\text { resources and the ecosystem }\end{array}$ & $\begin{array}{l}\text { Conservation of biological resources } \\
\text { and the ecosystem }\end{array}$ & $\begin{array}{l}\text { Conservation of resources, } \\
\text { biological resources and } \\
\text { the ecosystem }\end{array}$ \\
\hline 4 & $\begin{array}{l}\text { Education and training, extension } \\
\text { and empowerment of society in the } \\
\text { field of forestry }\end{array}$ & $\begin{array}{l}\text { Education and training, extension and } \\
\text { empowerment of society in the field } \\
\text { of forestry }\end{array}$ & - \\
\hline 5 & Regional watershed management & Regional watershed management & - \\
\hline 6 & Supervision of forestry & - & - \\
\hline
\end{tabular}

Table 2 shows that the authority of the central government in the forestry sector is still greater than that of the provincial and district/municipality governments. The central government has authority over six sub-affairs, whereas the provincial governments and the district/municipality governments have authority over only four sub-affairs and one sub-affair, respectively. The central government level continues to hold high authority even after the implementation of Law Number 23/2014, which indicates that forest management in Indonesia is centralised (Maryudi, 2016; Sahide et al., 2016; Simarmata \& Firdaus, 2016).

\subsubsection{Resource characteristics}

In North Sumatra Province, the implementation of Law Number 23/2014 did not encourage a change in the characteristics of forest resources controlled by the state (state property). Forest resources continue to have the characteristics of CPRs (Ostrom, 2008): (1) It is difficult to exclude other parties (individuals) from using goods through physical barriers or legal instruments (nonexcludable); (2) the benefits consumed by one individual reduces the benefits available to others (subtractable); (3) it is on a wide expanse of area; and (4) it is scattered and far from the reach of supervision.

After the implementation of Law Number 23/2014 in North Sumatra Province, the status of one forest was changed from state forest to customary (adat) forest in Humbang Hasundutan (Humbahas) Regency. This change in forest status was regulated in the Regional Regulation of Humbahas Regency Number 3/2019 dated 31 January 2019 on Recognition and Protection of the Customary Law Community (Masyarakat Hukum Adat or MHA) of Pandumaan-Sipituhuta, which will later be entitled to its own customary forest (Hutan adat or HA) area totalling 5,172 ha. It change in status of the forest is very important for MHA Pandumaan-Sipituhuta because it is a prerequisite for submitting an HA application to the Ministry of Environment and Forestry (MoEF).

By referring to the natural resources typology approach of Berge (2003) and the bundle of rights identified by Schlager and Ostrom (1992), the rights held by MHA Pandumaan-Sipituhuta on the HA can position it as the owner. That is, the owner is the party who has all the bundle of rights in the form of access rights (the right to enter a resource area), utilisation rights (the right to produce or use resources), management rights (the right to regulate the use and change the form of resources into certain products), exclusion rights (the right to determine who will have access) and transfer rights (the right to sell or lease one or more of the aforementioned rights). Further, Alston and Mueller (2005) stated that the more the number of rights to an asset that a person or a group owns, the greater the incentive to improve the asset value through investment; thus, the greater the 
allocation efficiency that can be expected. MHA Pandumaan-Sipituhuta is the 'owner' of the HA; however, the property rights regime is not that for a private property but that for a common property (i.e. collective ownership in which the right of access, use and management belongs to a group of clearly defined people through regional regulation).

Thus, the change in status from state forest to HA for MHA Pandumaan-Sipituhuta does not change the typology of goods and services from CPRs (with non-excludable but subtractable characteristics) to private goods (with excludable and subtractable characteristics) (Berge, 2003). The typology remains unchanged because it may be difficult to exclude individuals or other communities who are not entitled to use HA (i.e. high exclusion cost), there may be free riders because HA is a natural resource that is available and ready to be used by anyone, and the HA may be damaged following lack of compliance with the rules that apply in the MHA.

\subsubsection{Actors' behaviour}

The implementation of Law Number $23 / 2014$ has encouraged many actors to participate in forest management. A study on forest management in North Sumatra Province identified that 23 actors are involved in forest governance in this area (Affandi, 2020). To analyse stakeholders and their behaviour regarding implementing Law Number 23/2014 in North Sumatra Province, the present study describes a number of actors: the MoEF, the Provincial Regional People's Representative Council (Dewan Perwakilan Rakyat Daerah or DPRD) and the Provincial Government of North Sumatra, as the key actors; the Provincial Forestry Service, KPH, the licence holder/manager of a social forestry (SF) scheme and the licensing agent of a business that uses forest wood products (Izin Usaha Pemanfaatan Hasil Hutan Kayu or IUPHHK) as the primary actors; and non-government organisations and regency governments, as supporting actors (Fletcher et al., 2003).

Actors' forest governance behaviour is their adaptation to the implementation of the institutional structure and the characteristics of the forest resources. Their behaviour is affected by the level of interest, the power and the interactions among actors in achieving the objectives of each actor's activity, which will directly or indirectly affect the forest governance performance. Reed et al. (2009) defined interests as the motivations that drive actors' actions. Their power is actors' ability to affect others to act in accordance with their wishes. Table 3 presents details on these actors, their interests and power level, their commitments, and their behaviour in forest governance in North Sumatra Province after the implementation of Law Number 23/2014.

An actor involved in forest management, as listed in Table 3, is the license holder of the SF scheme, who is affected by other regulations (institutional structure), such as Regulation of MoEF Number P.83/2016. Based on Regulation of MoEF Number P.83/2016, Social Forestry is a management rights scheme for utilising forests that the state provides to the community. In this rule, the licence holder/SF scheme manager must implement binding provisions, starting from the Licence Application Procedure for each SF scheme (Chapter II) to the provisions on the Procedure for Utilizing SF Areas (Chapter III), Time Period and Evaluation (Chapter IV) and Rights and Obligations (Chapter V). These provisions indicate a contractual relationship between the government (as the licensor) and the SF scheme licence holder (as the recipient of the licence/right of management), which will affect the behaviour of the actors in achieving the SF program's objectives.

By referring to the perspective of the relationship between the principal and the agent (agency theory), the MoEF is positioned as the principal (licensor) and the licence holder/manager of the SF scheme as an agent (licensor; Quinn, 2013). As stated in the contractual Regulation of MoEF Number P.83/2016, the principal makes rules about forest use in the SF scheme to be used as guidelines and adhered to by agents. In its provisions, agents are required to manage principal forest resources in accordance with principal objectives. However, since these are natural resource management practices with contractual relationships, the principal does not eliminate the SF schemes that 
become national programs and do not achieve the expected goals, that is, improving prosperity, environmental balance and socio-cultural dynamics. ${ }^{3}$

Table 3. Actors, interests and power level, commitments, and actors' behaviour in forest governance in North Sumatra Province

\begin{tabular}{|c|c|c|c|c|c|}
\hline No & Actor & $\begin{array}{c}\text { Interest } \\
\text { level }\end{array}$ & $\begin{array}{c}\text { Power } \\
\text { Level }\end{array}$ & Commitment & Actor Behaviour \\
\hline \multicolumn{6}{|c|}{ Key Actors } \\
\hline 1 & $\begin{array}{l}\text { The Ministry } \\
\text { of } \\
\text { Environment } \\
\text { and Forestry } \\
\text { (MoEF) }\end{array}$ & High & High & $\begin{array}{l}\text { Implementing } \\
\text { GFG at the } \\
\text { local level } \\
\text { along with the } \\
\text { local } \\
\text { government } \\
\text { authority }\end{array}$ & $\begin{array}{l}\text { Cooperates with the Ministry of Home Affairs to compile } \\
\text { norms, procedures, standards and criteria; issues } \\
\text { supporting regulations related to forest governance in } \\
\text { local levels, such as: (1) The Regulation of The MoEF } \\
\text { Number P. } 64 / 2015 \text { on procedure for authorising Long- } \\
\text { Term Forest Management Plan (RPHJP) of Protection KPH } \\
\text { and Production KPH, (2) The Regulation of The MoEF } \\
\text { Number P. 74/2016 on guidelines for the nomenclature of } \\
\text { the Provincial and Regency/City Officials that perform } \\
\text { forestry affairs of government, (3) The Regulation of The } \\
\text { MoEF Number P.83/2016 on SF and (4) The Regulation of } \\
\text { The MoEF Number P. } 49 / 2017 \text { on forest utilisation } \\
\text { cooperation in KPH; and enforces laws in forest } \\
\text { governance. }\end{array}$ \\
\hline 2 & $\begin{array}{l}\text { Provincial } \\
\text { Legislative } \\
\text { Council }\end{array}$ & High & High & $\begin{array}{l}\text { Establishes } \\
\text { local } \\
\text { government } \\
\text { regulation to } \\
\text { manage } \\
\text { forestry } \\
\text { sectors and } \\
\text { contributes to } \\
\text { APBD }\end{array}$ & $\begin{array}{l}\text { On its own initiative or in cooperation with the provincial } \\
\text { government, compiles regulation on forest governance in } \\
\text { accordance with NSPC; supervises and controls the } \\
\text { implementation of local government regulations; drafts } \\
\text { the provincial budget and the regional expenditure and } \\
\text { revenue budget (Anggaran Pendapatan Belanja Daerah } \\
\text { or APBD); and planning. }\end{array}$ \\
\hline 3 & $\begin{array}{l}\text { Provincial } \\
\text { Government } \\
\text { (Governor) }\end{array}$ & High & High & $\begin{array}{l}\text { Achieves GFG, } \\
\text { and therefore } \\
\text { the } \\
\text { sustainability } \\
\text { and prosperity } \\
\text { of the } \\
\text { community, } \\
\text { and } \\
\text { contributes to } \\
\text { increasing } \\
\text { APBD }\end{array}$ & $\begin{array}{l}\text { In cooperation with the Provincial Legislative Council, } \\
\text { develops the provincial medium-term development plan } \\
\text { and APBD Plan and issues regulation that supports GFG, } \\
\text { such as: (1) The Regulation of The Governor Number } \\
38 / 2016 \text { on Local Officials Organizational Structure of } \\
\text { North Sumatra Province; based on that regulation, forest } \\
\text { management organisation in North Sumatra Province was } \\
\text { divided into } 16 \mathrm{KPH} \text { areas and one Forest Park; (2) The } \\
\text { Regulation of The Local Government of North Sumatra } \\
\text { Province Number } 2 / 2017 \text { on RTRWP of North Sumatra } \\
\text { year of } 2017-2037 ; \text { (3) the Decree of the Governor of } \\
\text { North Sumatra Province Number } 188.44 / 291 / K P T S / 2016 \\
\text { on Integrated Corruption Eradication Program Action } \\
\text { Plan; (4) The Regulation of The Governor of North } \\
\text { Sumatra Province Number } 19 / 2016 \text { on Guidelines for } \\
\text { Gratification Control in North Sumatra Province; (5) The } \\
\text { Regulation of The Governor of North Sumatra Province } \\
\text { Number } 77 / 2017 \text { on Smart Province Governance of North } \\
\text { Sumatra Province; and (6) develops draft regional } \\
\text { regulation on Forest Area Management of North Sumatra } \\
\text { Province (DPRD approval expected in 2020). }\end{array}$ \\
\hline
\end{tabular}

Primary Actors

\begin{tabular}{llll}
\hline $\begin{array}{l}\text { Provincial High Low Achieves GFG, } \\
\text { Forestry } \\
\text { Service }\end{array}$ & $\begin{array}{l}\text { Responsible for provincial government affairs in forestry } \\
\text { and therefore } \\
\text { sector, that is, in the subsectors of forest management, } \\
\text { the }\end{array}$
\end{tabular}

\footnotetext{
${ }^{3} \mathrm{SF}$ is a system of sustainable forest management implemented in state forest areas or customary forests/customary forests implemented by local communities or customary law communities as the primary actors to improve their prosperity, environmental balance and socio-cultural dynamics in the form of village forest (HD), community forest (HKm), community plantation forest (HTR), customary forest (HA) and forestry partnership (KK) (The Regulation of The MoEF P.83/2016)
} 


\begin{tabular}{|c|c|c|c|c|c|}
\hline No & Actor & $\begin{array}{c}\text { Interest } \\
\text { level }\end{array}$ & $\begin{array}{l}\text { Power } \\
\text { Level }\end{array}$ & Commitment & Actor Behaviour \\
\hline & & & & $\begin{array}{l}\text { sustainability } \\
\text { and prosperity } \\
\text { of the } \\
\text { community, } \\
\text { and also } \\
\text { contributes to } \\
\text { increasing } \\
\text { APBD }\end{array}$ & $\begin{array}{l}\text { ecosystem, training, counselling and community } \\
\text { empowerment and river basin area management; } \\
\text { conducts policy formulation, administration and also } \\
\text { evaluation and reports related to provincial government } \\
\text { affairs in forestry sector; prepares Provincial Forestry Plan } \\
\text { (RKTP) and Strategic Plan (Renstra) of Forestry OPD; } \\
\text { facilitates proposals of RPHJP and Short Term Forest } \\
\text { Management Plan (RPHJPd) of KPH; and facilitates } \\
\text { implementation of SF program. }\end{array}$ \\
\hline 5. & $\begin{array}{l}\text { Forest } \\
\text { Management } \\
\text { Unit (KPH) }\end{array}$ & High & Low & $\begin{array}{l}\text { Achieves GFG, } \\
\text { and therefore } \\
\text { the } \\
\text { sustainability } \\
\text { and prosperity } \\
\text { of the } \\
\text { community, } \\
\text { and } \\
\text { contributes to } \\
\text { increasing } \\
\text { APBD }\end{array}$ & $\begin{array}{l}\text { Prepares RPHJP and RPHJPd of KPH; performs the forest } \\
\text { manager function at site level in accordance with RPHJP } \\
\text { and RPHJPd prepared; prepares to be the forest manager } \\
\text { at site level by applying the BLUD scheme; conducts } \\
\text { community empowerment by building partnerships in } \\
\text { forest management with other stakeholders in } \\
\text { accordance with The Regulation of The MoEF Number } \\
\text { P.83/2016 on SF and also in accordance with The } \\
\text { Regulation of The MoEF Number } 49 / 2017 \text { on Partnership } \\
\text { of Forest Utilization on KPH. }\end{array}$ \\
\hline 6. & $\begin{array}{l}\text { Manager of } \\
\text { SF scheme }\end{array}$ & High & Low & $\begin{array}{l}\text { Provides } \\
\text { access and } \\
\text { fulfils legal } \\
\text { rights to forest } \\
\text { to increase } \\
\text { community } \\
\text { prosperity and } \\
\text { environmental } \\
\text { sustainability }\end{array}$ & $\begin{array}{l}\text { Proposes licence and management in accordance with SF } \\
\text { scheme to the MoEF; manages forest area after the } \\
\text { licence issued in accordance with regulation enforced in } \\
\text { each SF scheme received (HKm, HTR, HD and Forestry } \\
\text { Partnership); performs every task in accordance with SF } \\
\text { scheme received based on The Regulation of The MoEF } \\
\text { Number P.83/2016 on SF. }\end{array}$ \\
\hline 7 & $\begin{array}{l}\text { Permit of } \\
\text { business of } \\
\text { utilising } \\
\text { forest wood } \\
\text { products } \\
\text { (IUPHHK) }\end{array}$ & High & Low & $\begin{array}{l}\text { Maximises } \\
\text { business } \\
\text { profits }\end{array}$ & $\begin{array}{l}\text { Conducts business in accordance with applicable } \\
\text { regulations; coordinates with the KPH as the supervisory } \\
\text { and monitoring team for permit holders. }\end{array}$ \\
\hline \multicolumn{6}{|c|}{ Supporting Actors } \\
\hline 8 & $\begin{array}{l}\text { Non- } \\
\text { Government } \\
\text { Organisations }\end{array}$ & Low & High & $\begin{array}{l}\text { Completes } \\
\text { work } \\
\text { programs and } \\
\text { empowers the } \\
\text { community. }\end{array}$ & $\begin{array}{l}\text { Organises work programs; assists, educates and } \\
\text { empowers the community to manage forest resources } \\
\text { sustainably; supervises forest management and forestry } \\
\text { sector licensing as social control as complements to } \\
\text { formal supervision by governmental institutions. }\end{array}$ \\
\hline 9 & $\begin{array}{l}\text { Regency } \\
\text { Governments }\end{array}$ & Low & Low & $\begin{array}{l}\text { Increases the } \\
\text { prosperity of } \\
\text { communities } \\
\text { around the } \\
\text { forest }\end{array}$ & $\begin{array}{l}\text { Not involved in forestry activity in development planning } \\
\text { document; conducts village community empowerment, } \\
\text { including villages around the forest through related OPD; } \\
\text { and facilitates community to form groups, such as farming } \\
\text { groups and BUMDes. }\end{array}$ \\
\hline
\end{tabular}

Source: Compiled by authors from interview and primary research data of 2018 .

The SF objectives can fail when agents manage forests in an unsustainable manner, which is triggered by a conflict (difference) of interests between principal and agent. These problems can be eliminated by drawing up an effective contract to align the interests of the principal and the agent more closely. The contract should be prepared by considering all aspects that can spur performance improvement and strengthen the agent's commitment to obtaining the goals desired by the principal. An effective contract can also minimise the likelihood of an agent's behaviour deviating in its performance (moral hazard; Quinn, 2013). Further, agents bound by a contract will have to use their licences/management rights in accordance with the rules and characteristics of the resources they use, that is, forest resources, as CPRs (Nugroho, 2016). 


\subsubsection{Performance}

Performance is the level of achievement of the results or outputs of a process (Kirana \& Ratnasari, 2017). In the context of forest management institutions, performance is the result of social interrelationships among actors in the institutional structure and the characteristics of forest resources (Nugroho, 2016).

\section{(1) Certainty of forest area}

The certainty of the forest area is closely related to the process of forest area gazettement, which clarifies land boundaries and determines forests that are village areas, community areas and government forest areas (Contreras-Hermosilla \& Fay, 2005). In contrast, forest areas that have not been optimally confirmed will cause poor forest use patterns, become a path for corruption, lead to overlapping use of the area and result in conflicting authority among state institutions, both centrallocal and intersectoral (Corruption Eradication Commission/KPK, 2012).

Based on the Decree of the MoEF RI Number SK.579/Menhut-II/2014 on Forest Areas of North Sumatra Province, the total forest area in the Province was 3,055,795.00 ha. In July 2017, it was determined as $1,725,266.43$ ha or around $56.46 \%$ (Ministry of Environment and Forestry, 2017). In accordance with Appendix of Law Number 23/2014, the forest area gazettement (as part of the certainty of forest areas) is only under the authority of the central government in the forest planning sub-affairs. Therefore, the high or low performance of the certainty of forest areas in North Sumatra Province is highly dependent on the high and low implementation of the forest area gazettement by the central government, which is marked by the widening of forest area gazettement (legality) and the recognition of stakeholders (legitimacy).

Ostrom (1990) stated that of the design principles that guarantee the sustainability of forest resource institutions characterised by CPRs, the completion of the gazettement of all forest areas in North Sumatra Province is among the most important actions to be conducted by both the central government and the local governments. The stipulation of all forest areas will ensure clarity on the boundaries of the management area, so that the resources and actors are clearly defined. Nopiansyah (2017) argued that unclear boundaries result in the uncertainty of management space among actors. This finding is in line with that of Ostrom (1990), who stated that if the user and resource boundaries of CPRs are not clearly defined, the resource owner will face the risk of resource use by people who do not participate in the business of supplying and maintaining CPRs.

The unfinished forest area gazettement in North Sumatra Province is due to not only the slow gazettement process of the central government but also the limited budget of the provincial government. The district and the community still exhibit resistance towards the forest area boundary. The incomplete determination of the forest area has caused increasing community claims, additional encroachment and the conversion of the forest area, the overlapping use of the forest area, illegal logging, and tenure conflicts. Therefore, the implementation of Law No. 23/2014 has failed to help solve the problem of unclear boundary setting owing to the jurisdictional boundary rules that address the sub-affairs of forest planning, which resulted in the central government having authority over the sub-affairs of forestry supervision (Forestry Service of North Sumatra Province, 2019).

Likewise, even if the forest area has been determined, it does not necessarily guarantee that it is free from third-party rights - third parties can still submit claims at any time even though the gazettement and determination of forest areas continues to run. This situation illustrates that the legitimacy of enacted forest areas is still categorised as low as a result of the process of forest area gazettement that is conducted in a non-participatory and more administrative manner (Sinabutar et al., 2014).

\section{(2) $\mathrm{KPH}$ operations at the site level}

$\mathrm{KPH}$ development was a priority for the certainty of forest area policy in the Ministry Forestry Strategic Plan 2010-2014 (Minister of Forestry Regulation P.51/2010). The target for KPH development by 2014 was to construct $120 \mathrm{KPH}$ units throughout Indonesia. These targets continued to be developed in the 2015-2019 National Medium-Term Development Plan. During this 
period, $120 \mathrm{KPH}$ units built in the 2010-2014 era were to be operated and 600 new KPH were to be built throughout the Indonesian forest area. To achieve these targets, all the roles that support the achievement of targets need to be maximised, whereas all the obstacles that potentially hinder target achievement need to be minimised (Forestry Service of North Sumatra Province, 2019; Setyarso et al., 2014). The site-level operations of $\mathrm{KPH}$ were related to its development performance. Some criteria were used as standards for assessing KPH development performance, including strengthening of forest management systems, regulatory support and the internalisation of KPH development programs (Hernowo \& Ekawati, 2014; Setyarso et al., 2014).

The KPH management system in North Sumatra Province is based on the Decree of the Minister of Forestry Number: SK.102/Menhut-II/2010 dated 5 March 2010 on the Establishment of Protected Forest Management Unit (KPH Lindung or $K P H L)$ and Production Forest Management Unit ( $K P H$ Produksi or KPHP) of North Sumatra Province. Based on this decree, the KPH unit area in North Sumatra Province consists of $33 \mathrm{KPH}$ units divided into $14 \mathrm{KPHL}$ units with an area of $\pm 1,364,497$ ha and 19 units of KPHP with an area of $\pm 1,831,884$ ha. In line with the implementation of Law Number 23/2014, North Sumatra Governor Regulation Number 38/2016 on the Organizational Structure of the Local Offices of North Sumatra Province regulates the forest management in North Sumatra Province conducted by the $\mathrm{KPH}$, which is divided into $16 \mathrm{KPH}$ areas.

Despite the formation of the KPH forest management system, local governments' full support related to regulations for institutionalising $\mathrm{KPH}$ operations has been lacking, especially regulations to support KPH to become independent and professional in the Badan Layanan Umum Daerah (BLUD) scheme. Consequently, North Sumatra has not had a single KPH implementing the BLUD scheme. Nugroho and Soedomo (2016) stated that the BLUD scheme is a KPH institution that is intended to be a semi-governmental organisation (quasi-public) so that it is able to conduct its public functions as well as private or business functions. KPH institutions must be able to respond quickly to field needs by suppressing bureaucratic processes. In addition, through the BLUD scheme, the operation of the KPH will reduce financial dependence on the government and increase the entrepreneurship of the KPH institution. Therefore, the provincial government should mainstream regulations in the regions with the target of issuing regional regulations to support the KPH in the BLUD scheme.

The internalisation of KPH development programs is intended to gather strength from various groups, including relevant government institutions and other parties (non-government) who are competent in forestry issues. This internalisation was marked by the public consultation about KPH development as an effort to develop an understanding of the KPH program and the institutionalisation of KPH development to the relevant actors. Institutionalising KPH development for related actors means that in making policies related to forest areas, these actors pay attention to, and link and synergise with, KPH development programs. Maryudi (2016) stated that the internalisation of development programs in the $\mathrm{KPH}$ is very closely related to the relationship between the $\mathrm{KPH}$ and other actors.

In general, the KPH development program in North Sumatra Province has been internalised by the parties. In terms of public consultation, most of the parties were aware of the existence and function of the $\mathrm{KPH}$. This knowledge was obtained from public consultation activities by the Forest Service and KPH or direct involvement in KPH activities. As for the institution of the KPH, other actors are marked by the facilitation of $\mathrm{KPH}$ activities, collaboration in the implementation of $\mathrm{KPH}$ activities and programs, synchronisation and coordination of the $\mathrm{KPH}$ work program, and research and community service activities.

\section{(3) The ratio of the use of forest areas by communities and corporations}

At the provincial level of North Sumatra, until January 2019, community rights and access to forests through the SF scheme continued to increase. Through the SF program, 102 licences were issued and the number of households involved were about 14,150 (Table 4). Table 4 shows that before 2014 (before the implementation of Law Number 23/2014), the forest land area managed by the community was only around $12,267.61$ ha and it continued to increase until it reached $61,961.95$ ha in 2018. Further, it is estimated that there was additional area of approximately 
49,694.34 ha by January 2019. Secco et al. (2014) and Fisher et al. (2018) stated that the addition to the SF schema area reflects an increase in community participation in forest management after the issuance of the SF policy through Regulation of MoEF Number P.83/2016.

Table 4. Details of SF scheme area achievement in North Sumatra Province (until January 2019)

\begin{tabular}{|c|c|c|c|c|c|c|c|c|c|}
\hline \multirow[b]{2}{*}{ No } & \multirow{2}{*}{ SF Scheme } & \multicolumn{6}{|c|}{ Reached area per year (hectare) } & \multirow{2}{*}{$\begin{array}{l}\text { Number } \\
\text { of } \\
\text { licences }\end{array}$} & \multirow{2}{*}{$\begin{array}{l}\text { Number of } \\
\text { households }\end{array}$} \\
\hline & & $<2014$ & 2015 & 2016 & 2017 & 2018 & Amount & & \\
\hline 1 & HD & 320.00 & 0 & 0 & $3,541.00$ & 516.00 & $4,377.00$ & 13 & 2,706 \\
\hline 2 & $\mathrm{HKm}$ & 137.00 & 610.00 & 0 & $5,690.00$ & $25,352.00$ & $31,789.00$ & 47 & 6,502 \\
\hline 3 & HTR & $11,810.61$ & $3,434.00$ & 0 & 215.00 & 0 & $15,459.61$ & 12 & 2,569 \\
\hline 4 & KK & 0 & 0 & 0 & 0 & $5,164.34$ & $5,164.34$ & 29 & 1,603 \\
\hline 5 & $\mathrm{HA}$ & 0 & 0 & 0 & 0 & $5,172.00$ & $5,172.00$ & 1 & 770 \\
\hline & Amount & $12,267.61$ & $4,044.00$ & 0 & $9,446.00$ & $36,204.34$ & $61,961.95$ & 102 & 14,150 \\
\hline
\end{tabular}

Source: 'Compiled by authors based on primary data collected in 2019.

Note: HD: village forests; HKm: Community forestry; HTR: Community forest plantation; KK: Kemitraan Kehutanan or Forestry Partnership; HA: Customary forests.

Despite an increase in the area of forest land managed by the community, this increase is still relatively small when compared with the total area of forest land managed by corporations, at about 709,983 ha. As a percentage, the area of forest utilisation by the community has only reached $8 \%$, whereas forest control by business actors has reached $92 \%$. The limited proportion of forest management by the community is caused by the low achievement of the target area of the SF scheme. Suharjito (2017) and Hardiyanto et al. (2018) stated that some obstacles to achieve the target area of SF are caused by (1) inadequate regulatory support; (2) low political and financial support from local governments; (3) the low capacity and capability of the community; and (4) the lack of availability of assistants, which is not optimal in assisting prospective recipients of SF licences.

\section{(4) Reduced unofficial costs in managing licences and forest utilisation}

One GFG performance indicator is marked by transparency in forest management and is managed by personnel who have high integrity so that the practice of corruption and bribery as unofficial costs were no longer found in forestry businesses at every level of government (Corruption Eradication Commission/KPK, 2018; Secco et al., 2014; UNDP Indonesia, 2015). In North Sumatra Province, after the implementation of Law Number 23/2014, the transparency aspect in forest management, which is associated with gratuities in the management of licences and the utilisation of forest area, has shown significant improvements.

Table 5. Matrix of opinions of business actors about managing licences and utilisation of forest area in North Sumatra Province

\begin{tabular}{|c|c|c|}
\hline No. & Question & Perception and percentage of respondent answers \\
\hline 1 & $\begin{array}{l}\text { Reduction in the costs of } \\
\text { forestry licensing }\end{array}$ & $\begin{array}{l}\text { All respondents (100\%) stated that the maintenance fees were in accordance } \\
\text { with the official costs. }\end{array}$ \\
\hline 2 & $\begin{array}{l}\text { Purpose of providing } \\
\text { unofficial fees }\end{array}$ & $\begin{array}{l}\text { All respondents }(100 \%) \text { stated that they did not currently provide unofficial } \\
\text { (additional) costs while processing licences and using the area. However, } \\
\text { previously, they often provided unofficial fees to speed up processing time. }\end{array}$ \\
\hline 3 & $\begin{array}{l}\text { Time taken (process) to } \\
\text { obtain a licence }\end{array}$ & $\begin{array}{l}\text { All respondents ( } 100 \%) \text { stated that during the } 2015-2018 \text { period, they did not } \\
\text { perform activities and processes to obtain a new licence. However, } 50 \% \text { stated } \\
\text { the normal process of submitting the annual work plan had been long, and } 50 \% \\
\text { stated the process was still long. }\end{array}$ \\
\hline 4 & $\begin{array}{l}\text { Grant of additional fees to } \\
\text { government officials to } \\
\text { accelerate exit licence }\end{array}$ & $\begin{array}{l}\text { All respondents }(100 \%) \text { stated that it was not fair. However, since the licensing } \\
\text { process often takes time and the service time is not standardised, it encourages } \\
\text { respondents 'to look for other ways' to ensure a faster licensing process. }\end{array}$ \\
\hline 5 & $\begin{array}{l}\text { Conditions that require } \\
\text { unofficial fees }\end{array}$ & $\begin{array}{l}\text { All respondents }(100 \%) \text { stated that they had never been forced to provide } \\
\text { unofficial fees. }\end{array}$ \\
\hline 6 & $\begin{array}{l}\text { Gift of money or goods to } \\
\text { officials in gratitude on } \\
\text { receiving permission }\end{array}$ & $\begin{array}{l}\text { All respondents }(100 \%) \text { stated that it was fair to offer a gift in gratitude. However, } \\
\text { the gratitude should be expressed within normal limits, and money or goods } \\
\text { need not be given. }\end{array}$ \\
\hline
\end{tabular}




\begin{tabular}{lll}
\hline No. & \multicolumn{1}{c}{ Question } & \multicolumn{1}{c}{ Perception and percentage of respondent answers } \\
\hline 7 & $\begin{array}{l}\text { Government efforts to } \\
\text { reduce transaction costs }\end{array}$ & $\begin{array}{l}\text { Among the respondents, } 50 \% \text { stated that there was a real effort to reduce } \\
\text { unofficial costs, and } 50 \% \text { said that there were action plans, but they were not yet } \\
\text { effective. }\end{array}$
\end{tabular}

Source: Interviews with four company leaders (August 2018), the holders of a business licence for using forest wood products.

The results of interviews with respondents in North Sumatra Province reveal that the costs of arranging forest utilisation plans and of administering forest products are not burdensome; the respondents never provided, and nor were they forced to concede, unofficial costs; processes managing utilisation plans are undertaken in a normal timeframe; and real efforts have been made to reduce unofficial costs (Table 5).

In North Sumatra Province, illegal fees have reduced after the implementation of Law Number $23 / 2014$ as supported by the following: the issuance of the Regulation of North Sumatra Governor 2016 on anti-corruption; the application of innovations in the online forest product administration system; and the implementation of coordination, supervision and prevention of corruption in the North Sumatra Province by the KPK in the National Movement to Save Natural Resources Program (Corruption Eradication Commission/KPK, 2018; Kartodihardjo et al., 2015; UNDP Indonesia, 2015).

\subsection{Institutional Analysis of Forest Governance After the Implementation of the Law Number $23 / 2014$}

\subsubsection{Jurisdiction of boundary}

The implementation of Law Number 23/2014 dismissed the jurisdictional boundaries of the regency/municipality forestry sector, thereby removing the range of control and effectiveness of forest management at the site level, which had been carried out by regencies/municipalities. In addition, in the division of sub-governmental affairs in the forestry sector between the central government and the provincial governments, the jurisdiction boundaries for provincial regions have narrowed. In this case, from the six sub-governmental affairs in the forestry sector, the provincial region does not have authority over the sub-affairs of forest planning and forestry supervision, which are reserved for the central government.

The narrowing of jurisdictional boundaries under Law Number 23/2014 has meant that provinces, including North Sumatra, cannot fully support forest management activities, such as forest inventory, forest area gazettement, forest area stewardship, the establishment of forest management areas (as a forest planning sub-affair) and the supervision of forest management (as a forestry supervision sub-affair), in terms of both budget and implementation. This lack of support will certainly affect the implementation of forest governance institutions, and the provinces cannot expand their jurisdictional boundaries to increase the GFG performance achievement when the central government has not exercised its authority over the sub-affairs under its jurisdiction in provincial areas.

In North Sumatra Province, a consequence of the narrowing of the jurisdiction boundary is visible in the performance indicator of 'predetermined forest area', which is only about $56.46 \%$ (or an area of 1,725,266.43 ha from 3,055,795.00 ha of the total forest area of this Province) until 2017. The incomplete determination of the entire forest area has made forest areas in North Sumatra Province prone to tenurial conflicts due to the claims of contesting parties. This situation has occurred despite the fact that completing the designation of all forest areas is among the most important steps needed to strengthen forest area certainty and clarify boundaries and claims for forest management areas. The determination of this forest area is also very useful in clarifying the boundaries of jurisdiction to all stakeholders, as a component of forest management that is characterised by sustainable CPRs in improving forest governance performance (Ostrom, 1990). 


\subsubsection{Rules of representation}

Law Number 23/2014 strongly encourages public (stakeholders') participation in regional governance, including forest management. Public participation includes the following: (1) formulating regional regulations and regional policies to regulate forest management, and (2) planning, budgeting, implementing, monitoring and evaluating forest management. Further, it is expected that public participation will result in regional development policies in the forestry sector that accord with the objectives of forestry sector decentralisation; that is, to bring public services closer to the community and to manage forest resources in a sustainable manner for community welfare (Colfer \& Capistrano, 2005).

However, the opportunity to ensure community participation in practice has not encouraged local governments, including the North Sumatra Province, to produce policies in forest management that are in accordance with regional interests. This is in line with the results of studies that show that, after the implementation of Law Number 23/2014, the rules used in forest governance in North Sumatra Province are generally still dominated by regulations originating from the central government. In fact, the Provincial Government of North Sumatra has only been able to issue regulations directly related to forest management in the form of (1) Governor Regulation Number 48/2017 on Duties, Functions, Job Descriptions and Work Procedures of the North Sumatra Provincial Forestry Service, which divides forest management organisations in North Sumatra Province into $16 \mathrm{KPH}$ Areas and one Grand Forest Park Office; and (2) a draft of regional regulations on Management of the Forest Area of North Sumatra Province in 2019.

After the implementation of Law Number 23/2014, the Provincial Government of North Sumatra has not made many representation rules on forest management under its authority, which exemplifies the lack of representation rules for forest management in the regions. Yusdiyanto (2012) stated that the low level of representation rules is caused by (1) a weakness in the hierarchical system of legislation, namely, that regional regulations made by provincial regions must refer to higher regulations, and (2) the low ability of provincial governments to compile policy (legislative process) regarding forest management.

One example of the low level of representation rules for forest management in North Sumatra Province relates to the case of SF policy implementation. Until date, North Sumatra Province does not have a governor's regulation regarding the facilitation of SF development as a form of governor's representation rules. In accordance with the MoEF Regulation No. P.83/2016, the governor has the authority (right) in the decision-making process to grant the SF scheme licence as a form of delegation from the MoEF. From an economic perspective, if the governor exercises authority, it will reduce decision-making costs, thereby reducing the costs of economic transactions and accelerating the performance achievement of the SF scheme area.

However, the delegation requires the provincial governments to have included the SF program in the provincial medium-term development plan and to have funding support as outlined in the provincial APBD. Because the delegation requirements have not been fulfilled, the application for the SF scheme in North Sumatra Province cannot be submitted to the governor and must be submitted to the MoEF. This condition influences the low performance as regards achieving the target area for forest management through the SF scheme. Data analysis shows that the development of the SF program in North Sumatra Province until January 2019 has only been realised up to an area of $61,961.95$ ha (11.25\%) as against the SF program target of 550,887 ha according to the Social Forestry Area Indicative Map of North Sumatra Province.

Based on this explanation, the implementation of Law Number 23/2014 in the context of representation rules in North Sumatra Province indicates at least the following: (1) The narrowing of jurisdictional boundaries for provincial areas in forest management results in low representation rules in forest management; (2) the high dominance of the central government in drafting 'uniform' regulations reduces the opportunities for provincial regions to formulate regulations based on their uniqueness (local-specific) as a manifestation of the principle of representation, and (3) various requirements in implementing central government regulations contribute to the low performance as regards the achievement of the objectives of issuing these regulations. 


\subsubsection{Property rights}

Forests in North Sumatra Province are divided into state, private and customary forests, which indicates the legal certainty of property rights over forest resources. Regarding the status of state forests, the property rights lie with the state, which controls the rights to access, use and manage them. The state also has the right to transfer the rights to these goods/commodities to other parties (Hanna et al., 1996). Specifically, management rights related to state forests under a provincial authority (i.e. HP, HL and Tahura) are divided into three types: (a) self-management by KPH and Tahura, (b) transfer of management to individuals (private) through IUPHHK-natural forest/plantation forest and IUPHHK HTR schemes (individual licence holders) and (c) transfer of management to groups collectively (common) in the form of SF schemes, such as HKm, IUPHHK HTR (group licence holders), HD and KK.

These three types of forest management rights are a form of transfer of temporary property rights granted by the government through a system of management rights and business permits in accordance with applicable regulations (Kartodihardjo, 2008; Nugroho, 2016). This transfer of ownership rights closely relates to clarity in determining who should manage the forest and who should receive the related benefits. In addition, clarity on the transfer of property rights is also important in regulating bundles of rights, such as the rights of access, withdrawal, management, exclusion and alienation. This is in accordance with the position of the rights holder, whether as owner, proprietor, claimant or user (Schlager \& Ostrom, 1992).

In North Sumatra Province, property rights over state forests have generally received recognition from the government, which is strengthened in formal legal rules (de jure) for managers (KPH/Tahura) and permit holders (IUPHHK and holders of SF scheme) through a decree of the Minister of Environment and Forestry. For example, for KPH there is a Decree of the Minister of Forestry Number: SK. 102/Menhut-II/2010 dated 5 March 2010 on the Designation of Protected Forest Management Units and Production Forest Management Units of North Sumatra Province. The decree identified 14 KPHL units and 19 KPHP units. For the SF scheme, a Decree of the Minister of Environment and Forestry was issued in 2017 for 102 permits consisting of $47 \mathrm{HKm}$ scheme permits, 29 KK scheme permits, 13 HD scheme permits, 12 HTR scheme permits and one Customary Forest scheme permit (Forestry Service of North Sumatra Province, 2019). These formal legal rules (legality) officially grant licence managers and holders a set of rights, such as accessing, utilising, managing, limiting and controlling other parties' use of forest resources. In addition, this legality can minimise the level of conflicts caused by the claims of other parties in the management of forest resources and the land.

Nevertheless, the legality of property rights over a forest area does not guarantee that it will be free from claims by other parties; thus, this situation may reduce the guarantees about property rights (Broegaard, 2005). In the Province of North Sumatra during 2018, there were 15 cases of forest area claims by the community, which resulted in tenurial conflicts; 21 cases of encroachment of forest areas; and many cases of illegal logging activities (Forestry Service of North Sumatra Province, 2019).

After the implementation of Law Number 23/2014, North Sumatra Province also has problems regarding property rights to forest resources. This problem can be found in the level of rights of the manager and permit holder, which is generally limited to being a tenant (claimant), namely, the party who only has the rights to access, use and manage the property (Schlager \& Ostrom, 1992). As tenants, managers and licence holders must comply with the lessee's rules, including the rules that limit tenants' rights. For tenants, there are limitations to the rules of representation -they do not have the right to determine who can access, transfer and sell or rent the property. Owing to these limitations, property rights are imperfect, and hence, the allocation of forest resources is less efficient in the market economy (Alchian \& Demsetz, 1973). In fact, property rights matter because they determine resource use. The more exclusive are the property rights to the individual or group, the greater the incentive to maintain the asset value. Further, more exclusive rights increase the incentive to improve the asset value through investment (Alston \& Mueller, 2005). 


\subsection{Strategy for Strengthening Forest Governance Institutions in North Sumatra Province}

The institutional performance achievements and institutional analysis show that the implementation of Law Number 23/2014 has failed to significantly encourage the improvement of forest governance performance in provincial areas. Therefore, the institutional aspects of forest governance need strengthening as described in the following sections.

\subsubsection{Institutional innovation}

Institutional innovation is interpreted as an improvement in institutional aspects that, in turn, improves performance (Nugroho, 2016). This institutional improvement is a form of institutionalisation and serves as a legal umbrella to strengthen the effectiveness of the implementation of Law Number 23/2014 in supporting improved forest governance performance.

1) Jurisdictional boundaries. The jurisdiction boundary for provincial regions can be extended so that they have full authority (autonomy) over all forest management sub-affairs. To this end, applicable regulations must be revised or the assistance mechanism for completing tasks related to the sub-affairs of forest planning and forestry supervision must be strengthened. Specifically, for successful task completion, in accordance with the applicable regulations, task assignment must be accompanied by the provision of financing, human resources support, technical assistance, and facilities and infrastructure. Assistance tasks can be directly assigned to the KPH as the site-level forest manager and task implementation can be coordinated with the UPT of MoEF in the regions. Apart from co-administration through KPHs, jurisdictional boundaries in forest management at the provincial level can also be expanded through a forestry partnership scheme. Such schemes are a multilevel, multi-actor method of forest governance, often referred to as polycentric governance (Nagendra \& Ostrom, 2012). Multilevel governance enables parties such as ministerial and institutional officials (at the national, provincial and district levels), investors and residents to negotiate, formulate and implement forest management policies jointly. Meanwhile, multi-actor governance requires collaboration between different parties to achieve the goals of public policies (Forsyth, 2009).

2) Representation rules. Institutional innovation in the rules of representation can be conducted by opening space for active participation in the national policy formulation process and by implementing a public consultation mechanism with stakeholders at the regional level. This effort is performed as a form of representation to ensure the public legitimacy of proposed policies. In addition, innovation can be brought about by strengthening the position of regional regulations in the hierarchical system of legislation by encouraging the emergence of various local-specific rules of representation at the site level, which would also serve as a manifestation of the rules of representation. Thus, clarity and accuracy of regulations will be generated according to regional needs and can be a control for resource sustainability (Ostrom, 1990).

3) Property rights. Ownership rights over resources are often unclear; thus, open access can accelerate resource damage. Therefore, clear ownership rights are essential to (1) regulate the rights and obligations of rights holders, and (2) to provide certainty about the management and the current and future benefits that will be obtained (Pakpahan, 1989). Efforts that can be made include the following: (1) Community participation must be ensured in the process of determining forest areas so that there is legal (de jure) and real (de facto) recognition of land status. This recognition closely relates to the support of the community in managing an area (Contreras-Hermosilla \& Fay, 2005; Corruption Eradication Commission/KPK, 2012). (2) The position of the managers and licence holders must be changed from being limited to 'claimants', namely, parties who only have the rights to access, use and manage the asset become 'proprietors'. With proprietary status, licence managers and holders will have access rights, use rights, management rights and exclusion rights. Through the right of exclusion, they will have the right to determine who can have access rights and select the method for transferring these access rights to other parties, such as through bequeathing/giving, but will not have the right to sell the asset (Schlager \& Ostrom, 1992). 


\subsubsection{Strengthening the capability of forestry actors in the regions}

Implementation of Law Number 23/2014 has encouraged the involvement of various actors in forest management in North Sumatra Province, that is, key, primary and supporting actors. As already explained, a component driving the success of forest governance is the actors' capability. If the capability of key actors, such as the DPRD and the provincial governments, is strengthened, both would have high capacity in the legislation process related to forest management and the provincial governments' political will to support GFG would increase.

Strengthening the capabilities of the primary actors-particularly the KPH, permit holders and managers of the SF schemes-is intended to enable them to have the skills for site-level forest management. For KPHs, this capability strengthening would be very useful in developing forest management through the BLUD scheme. The Provincial Government of North Sumatra must prioritise the strengthening of KPH capabilities because KPH development is intended to address the need for forest management units at the site level and their management organisations to achieve forest sustainability. Meanwhile, for permit holders and managers of SF schemes, capability strengthening would contribute significantly to enhancing the values of entrepreneurship in using their business permits.

\section{Conclusion}

The withdrawal of forestry sector authority from regencies/municipalities to the provincial and central governments has failed to resolve fundamental, site-level problems in forest management. This situation illustrates that the implementation of Law Number 23/2014 has been ineffective in encouraging improvements in forest governance performance. This finding is based on the assessment of forest governance performance using a framework of the relationship between performance and institutional structure, forest resource characteristics and actors' behaviour. The assessment results show that forest management authority is delegated in provincial and central forest areas with a centralised nuance, the characteristics of forest resources remain unchanged (i.e. these continue to be CPRs) and the behaviour of actors interested in forest management lacks synergy, resulting in low values for forest governance performance indicators.

The results of an institutional analysis on the aspects of jurisdictional boundaries, the rules of representation and the ownership rights after the implementation of Law Number 23/2014 show that forest governance in a decentralised system, which divides authority between government levels, will be effective in supporting the success of forest governance performance provided the following conditions are met: (1) There is an appropriate, balanced division of authority between government levels based on capability and their respective needs. (2) The government and central institutions use a participatory approach to create and establish regulations or policies in which the decentralised system will be enforced. (3) There is tenure security and clarity of ownership, which will reduce claims and conflicts in the management and use of forest resources. (4) There is a legal umbrella and the capacity to resolve conflicts and negotiations between various parties who have varying levels of interest and power.

Author contributions: Hariadi Kartodihardjo, Bramasto Nugroho and Sulistya Ekawati designed the concept of research and analysed the data; Oding Affandi designed and performed the research, analysed the data and led the paper-writing effort.

Competing interests: The authors declare that they have no competing interests.

Acknowledgement: The authors extend their acknowledgement to the Ministry of Research, Technology and Higher Education of the Republic of Indonesia for the scholarship support. Sincere appreciation is also extended to the anonymous reviewers for their corrections and comments.

\section{References}

Affandi, O. (2020). Kelembagaan dan inovasi daerah dalam tata kelola hutan setelah implementasi UU No. 23/2014 di Provinsi Sumatera Utara [Institutions and regional innovation in forest 
governance following the implementation of Law Number 23/2014 in North Sumatra Province] [Unpublished doctoral dissertation]. Program Pascasarjana. IPB University.

Alchian, A., \& Demsetz, H. (1973). The property rights paradigm. The Journal of Economic History, 33, 16-27. http://doi.org/10.1017/\$0022050700076403

Alston, L. J., \& Mueller, B. (2005). Property rights and the state. In C. Menard, \& M. M. Shirley (Eds.), Handbook of New Institutional Economics (pp. 149-172), Springer. https://doi.org/10.1007/0387-25092-1

Basyuni, M., Sulistiyono, N., Wati, R., \& Hayati, R. (2018). Deforestation trend in North Sumatra over 1990-2015. IOP Conference Series: Earth and Environmental Science, 122(1). https://doi.org/10.1088/1755-1315/122/1/012059

Berge, E. (2003, July 11-14). Environmental protection in the theory of commons [Paper presentation]. Trans-nationalizing the commons and the politics of civil society, Chiang Mai, Thailand. http://www.sv.ntnu.no/iss/Erling.Berge/IASCP03 Chiang Mai 2003.pdf

Broegaard, R. J. (2005). Land tenure insecurity and inequality: A case study from Nicaragua. Development and Change, 36(5), 845-864. http://doi.org/10.1111/j.0012-155X.2005.00438.x

Colfer, C. J. P., \& Capistrano, D. (Eds.). (2005). The politics of decentralization: Forests, people and power. Earthscan.

Contreras-Hermosilla, A., \& Fay, C. (2005). Strengthening forest management in Indonesia through land tenure reform: Issues and framework for action. World Agroforestry. https://www.foresttrends.org/publications/strengthening-forest-management-in-indonesia-through-landtenure-reform/

Corruption Eradication Commission (Komisi Pemberantasan Korupsi). (2012). Integrated white paper: Semiloka menuju kawasan hutan yang berkepastian hukum dan berkeadilan [Workshop towards forest areas with legal certainty and justice] [White paper]. Author. https://auriga.or.id/related/detail/25/integrated-white-paper-semiloka-menuju-kawasanhutan-yang-berkepastian-hukum-dan-berkeadilan?lang=id

Corruption Eradication Commission (Komisi Pemberantasan Korupsi). (2018). Kertas kebijakan evaluasi gerakan nasional penyelamatan sumberdaya alam [Policy paper on evaluation of the national movement to save natural resources]. Author.

Fisher, M. R., Moeliono, M., Mulyana, A., Yuliani, E. L., Adriadi, A., Judda, J., \& Sahide, M. A. K. (2018). Assessing the new social porestry project in Indonesia: Recognition, livelihood and conservation? International Forestry Review, 20(3), 346-361. https://doi.org/10.1505/146554818824063014

Fletcher, A., Guthrie, J., Steane, P., Roos, G., \& Pike, S. (2003). Mapping stakeholder perceptions for a third sector organization. Journal of Intellectual Capital, 4(4), 505-527. https://doi.org/10.1108/14691930310504536

Food and Agriculture Organization Program on Forests. (2011). Framework for assessing and monitoring forest governance. FAO PROFOR, 36. http://www.fao.org/climatechange/275260cc61ecc084048c7a9425f64942df70a8.pdf

Forestry Service of North Sumatra Province. (2019). Rencana Strategis (Renstra) Dinas Kehutanan Provinsi Sumatra Utara Tahun 2019-2023 [The Strategic Plan of the Forestry Service of North Sumatra Province for 2019 - 2023]. Dinas Kehutanan Provinsi Sumatera Utara.

Forsyth, T. (2009). Multilevel, multiactor governance in REDD+. Participation, integration and coordination. In A. Angelsen (Eds.), Realising REDD+. National strategy and policy option (pp. 113-122). Center for International Forestry Research.

Handayani, M. M., Fajrini, R., \& Subagiyo, H. (2019). Indeks kelola hutan dan lahan 2019: Studi endline tata kelola hutan dan lahan di 12 provinsi [Forest and land governance index 2019: Endline study of land and forest governance in 12 provinces]. Indonesian Center for Environmental Law. https://icel.or.id/hasil-penelitian/indeks-kelola-hutan-dan-lahan-2019studi-end-line-tata-kelola-hutan-dan-lahan-di-12-provinsi/

Handoyo, R. K. D., \& Irawanti, S. (2013). Kebijakan [Policy]. In K. D. Raharjo, H. Dwiprabowo, S. Irawanti, \& N. dan Ginting (Eds.), Pedoman analisis penelitian sosial ekonomi kehutanan [Guidelines for forestry socio-economic research analysis] (pp. 351-414). PT Kanisius 
Hanna, S. S., Folke, C., \& Maler, K. G. (1996). Rights to nature: Ecological, economic, cultural and political principles of institutions for the environment. Island Press.

Hardiyanto, G., Adnan, H., \& Santosa, A. (2018). Percepatan implementasi program perhutanan sosial [Accelerating the implementation of social forestry programs]. https://fkkm.org/2018/09/27/policy-paper-percepatan-implementasi-program-perhutanansosial/

Hernowo, B., \& Ekawati, S. (2014). Operasionalisasi kesatuan pengelolaan hutan (KPH): Langkah awal menuju kemandirian [Operationalization of forest management units (FMUs): The first step towards independence]. PT. Kanisius.

Indonesian Center for Environmental Law \& SEKNAS FITRA. (2015). Policy brief tata kelola yang tak kunjung membaik: penilaian masyarakat sipil terhadap kinerja pemerintah daerah dalam pengelolaan hutan dan lahan di 16 kabupaten [Policy brief: governance that is not improving: civil society assessment of local government performance in forest and land management in 16 districts]. https://programsetapak.org/wp-content/uploads/2016/10/Indeks-Tata-KelolaHutan-Lahan-2015.pdf

Indrarto, G. B., Purba, C., Steni, B., Tresya, D., Dewantama, M., Hartati, C., Apriani, I., \& Putri, A. (2012). Potret pelaksanaan tata kelola hutan. sebuah studi mendalam di Provinsi Kalimantan Tengah dan Nusa Tenggara Barat. Jaringan Tata Kelola Hutan Indonesia.

Kartikasari, F. I., Priyanta, M., Tresya, D., \& Kusumawardhani, W. (2012). Perizinan terpadu untuk perbaikan tata kelola hutan di Indonesia: Studi kasus Kalimantan Tengah. Indonesian Center for Environmental Law.

Kartodihardjo, H. (2006). Masalah kapasitas kelembagaan dan arah kebijakan kehutanan: Studi tiga kasus [Problem of institutional capacity and direction of forestry policy: Three cases study]. Jurnal Manajemen Hutan Tropika, 12(3), 14-25.

Kartodihardjo, H. (2008). Di balik kerusakan hutan dan bencana alam: Masalah transformasi kebijakan kehutanan [Behind forest destruction and natural disasters: The problem of forest policy transformation]. Wana Aksara.

Kartodihardjo, H. (2013). Kepemerintahan dan kebijakan kehutanan: Soal diskursus dan reduksi ilmu pengetahuan [Forestry governance and policy: A matter of discourse and knowledge reduction]. In H. Kartodihardjo (Ed.), Kembali ke jalan lurus: Kritik penggunaan ilmu dan praktek kehutanan Indonesia [Getting back on track: Criticism of the use of forest science and practice in Indonesia] (pp. 149-176). FORCI Development dan Tanah Air Beta.

Kartodihardjo, H., Sunaryo, Situmorang, A. W., Soeprihanto, P., Hadi, J. W., Nurtjahjawilasa, \& Fach, E. (2015). Kajian perizinan kehutanan online: Menuju terwujudnya perbaikan tata kelola hutan indonesia [Online forestry permit review: Towards the realization of improved Indonesian forest governance]. Kementerian Lingkungan Hidup dan Kehutanan.

Kirana, K. C., \& Ratnasari, R. T. (2017). Evaluasi kinerja sumberdaya manusia [Evaluation of human resource performance]. Gosyen Publishing.

Maryudi, A. (2016). Arahan tata hubungan kelembagaan kesatuan pengelolaan hutan (KPH) di Indonesia [Direction of institutions and bureaucracies of forest management units (FMUs) in Indonesia]. Jurnal Ilmu Kehutanan, 10(1), 57-64. https://doi.org/10.22146/jik.12632

Ministry of Environment and Forestry. (2017). Penetapan kawasan hutan menuju kawasan hutan indonesia yang mantap [The forest area gazettement towards a solid Indonesian forest area]. Author.

Ministry of Home Affairs. (2011). Naskah akademik rancangan undang-undang (RUU) tentang Pemerintahan Daerah usul inisiatif pemerintah [Academic paper of the draft law on Regional Government proposed by the government].

Moeliono, M., Wollenberg, E., \& Limberg, G. (Eds.). (2008). The decentralization of forest governance: Politics, economics and the fight for control of forests in Indonesian Borneo. Earthscan Publications

Nagendra, H., \& Ostrom, E. (2012). Polycentric governance of multifunctional forested landscapes. International Journal of the Commons, 6(2), 104-133. http://doi.org/10.18352/ijc.321

Nopiansyah, F. (2017). Penguatan kelembagaan lokal pengelolaan sumber daya alam sumber 
penghidupan Suku Mentawai di Cagar Biosfer Pulau Siberut [Strengthening local institutions for the management of natural resources as a source of livelihood for the Mentawai Tribe in the Siberut Island Biosphere Reserve] [Unpublished doctoral dissertation]. Program Pascasarjana. IPB University.

North, D. C. (1990). Institutions, institutional change and economic performance. Cambridge University Press. https://doi.org/10.1017/СBO9780511808678

Nugroho, B. (2013). Reformasi kelembagaan dan tata kepemerintahan: Faktor pemungkin menuju tata kelola kehutanan yang baik [Institutional reform and governance: Enabling factors for good forest governance]. In Kartodihardjo (Eds.), Kembali ke jalan lurus: Kritik penggunaan ilmu dan praktek kehutanan Indonesia [Getting back on track: Criticism of the use of forest science and practice in Indonesia] (pp. 177-224). FORCI Development dan Tanah Air Beta.

Nugroho, B. (2016, 26 November). Kelembagaan, karakteristik sumberdaya, dan perilaku aktor: Analisis kritis kebijakan pengelolaan hutan Indonesia [Institutions, resource characteristics, and actor behavior: A critical analysis of Indonesia's forest management policies]. Orasi IImiah Guru Besar Tetap Fakulas Kehutanan Institut Pertanian Bogor. Institut Pertanian Bogor.

Nugroho, B., \& Soedomo, S. (2016). Panduan pola pengelolaan keuangan badan layanan umum daerah (BLUD) menuju kemandirian KPH [Guidelines for the pattern of financial management of regional public service agencies (BLUD) towards the independence of FMUs]. Kementerian Lingkungan Hidup dan Kehutanan

Ostrom, E. (1990). Governing the commons: The evolution of institutions for collective action. Cambridge University Press. https://doi.org/10.1017/CBO9780511807763

Ostrom, E. (2005). Understanding institutional diversity. Princeton University Press. https://doi.org/10.1515/9781400831739

Ostrom, E. (2008). Institutions and the environment. Economic Affairs, 28(3), 24-31. https://doi.org/10.1111/j.1468-0270.2008.00840.x

Pakpahan, A. (1989). Kerangka analitik untuk penelitian rekayasa sosial: Perspektif ekonomi institusi [Analytical framework for social engineering research: Institutional economic perspective]. Prosiding Patanas Evolusi Kelembagaan Pedesaan Di Tengah Perkembangan Teknologi Pertanian.

Peters, B. G. (2000). Institutional theory: Problems and prospects. Political Science Series, 69(69). http://opensigle.inist.fr/handle/10068/86548

Quinn, J. J. (2013). Teori prinsipal agen [Principal agent theory]. In Ishiyama, \& Breuning (Eds.), IImu politik dalam paradigma abad kedua puluh satu. Sebuah referensi panduan praktis. Jilid 1 [21 ${ }^{\text {st }}$ century political science: A reference handbook. Volume 1]. Prenada Media Group.

Rachman, B. (2009). Kebijakan sistem kelembagaan pengelolaan irigasi: Kasus Provinsi Banten [Policy on institutional system of irrigation management: The case of Banten Province]. Analisis Kebijakan Pertanian, 7(1), 1-19. http://pse.litbang.deptan.go.id/ind/pdffiles/ART71a.pdf

Rahman, Y., Hartati, C., Maulana, M., Subagiyo, H., \& Putra, R. A. (2013). Indeks kelola hutan dan lahan daerah: kinerja pemerintah daerah dalam pengelolaan hutan dan lahan di Indonesia: Studi kasus pada 9 kabupaten [Local forest and land management index: local government performance in forest and land management in Indonesia: Case study in 9 districts]. ICEL dan SEKNAS FITRA.

Reed, M. S., Graves, A., Dandy, N., Posthumus, H., Hubacek, K., Morris, J., Prell, C., Quinn, C. H., \& Stringer, L. C. (2009). Who's in and why? A typology of stakeholder analysis methods for natural resource management. Journal of Environmental Management, 90(5), 1933-1949. https://doi.org/10.1016/j.jenvman.2009.01.001

Sahide, M. A. K., Supratman, S., Maryudi, A., Kim, Y.-s., \& Giessen, L. (2016). Decentralisation policy as recentralisation strategy: Forest management units and community forestry in Indonesia. International Forestry Review, 18(1), 78-95. https://doi.org/10.1505/146554816818206168

Schlager, E., \& Ostrom, E. (1992). Property-rights regimes and natural resources: A conceptual analysis. Land Economics, 68(3), 249-262. https://doi.org/10.2307/3146375

Schmid, A. A. (2004). Conflict and cooperation: Institutional and behavioral economics. Blackwell 
Publishing.

Secco, L., Da Re, R., Pettenella, D. M., \& Gatto, P. (2014). Why and how to measure forest governance at local level: A set of indicators. Forest Policy and Economics, 49, 57-71. https://doi.org/10.1016/j.forpol.2013.07.006

Setyarso, A., Djajono, A., Nugroho, B., Wulandari, C., Suwarno, E., Kartodihardjo, H., \& Sardjono, M. A. (2014). Strategi pengembangan KPH dan perubahan struktur kehutanan Indonesia [KPH development strategy and changes in Indonesia's forestry structure]. www.forclime.org

Simarmata, R., \& Firdaus, A. Y. (2016). Pemberlakuan UU No. 23/2014 dan desentralisasi di bidang pengelolaan sumberdaya alam [The enactment of Law No. 23/2014 and decentralization in the field of natural resource management]. Perkumpulan untuk Pembaharuan Hukum Berbasis Masyarakat dan Ekologis (HuMa).

Sinabutar, P., Nugroho, B., Kartodihardjo, H., \& Darusman, D. (2014). Reforming the gazettment of state forest area in Riau Province. Jurnal Manajemen Hutan Tropika, 20(3), 179-186. https://doi.org/10.7226/jtfm.20.3.179

Suharjito, D. (2017). Percepatan pencapaian target perhutanan sosial. Disampaikan pada konferensi tenurial [Accelerating the achievement of social forestry targets. Presented at the tenure conference]. Jakarta, 25-27 Oktober 2017 dengan Tema "Mewujudkan Hak-hak Rakyat: Reformasi Penguasaan Tanah dan Pengelolaan Hutan di Indonesia". http://fkkm.org/wpcontent/uploads/2017/10/Panel-1-Perhutanan-Sosial-Tenure-Conference-2017.pdf

United Nations Development Programme Indonesia. (2013). Indeks Tata Kelola Hutan, Lahan dan REDD+ 2012 di Indonesia [The 2012 Indonesia forest, land, and REDD+ governance index]. https://www.id.undp.org/content/indonesia/en/home/library/environment_energy/indekstata-kelola-hutan---lahan--dan-redd--2012-di-indonesia.html

United Nations Development Programme Indonesia. (2015). Indeks Tata Kelola Hutan Indonesia 2014 [The 2014 Indonesia forest governance index]. http://www.menlhk.go.id/

Yusdiyanto. (2012). Partisipasi masyarakat dalam pembentukan program legislasi daerah [Community participation in the establishment of regional legislation programs]. Fiat Justitia Jurnal IImu Hukum Fakultas Hukum Universitas Lampung, 5(2), 1-13. https://doi.org/10.25041/fiatjustisia.v5no2.66 